\title{
Scientific Study on Trigonella Foenum-Graecum (Fenu Greek) with Special Reference to its Preclinical Study on Antidiabetic Effect
}

ISSN: 2578-0263

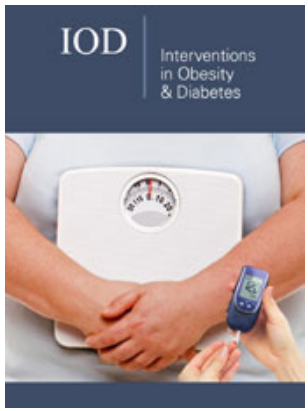

*Corresponding author: Mohammad Kamil, TCAM Research, ZCHRTM, Abu Dhabi, United Arab Emirates

Submission: 率 October 17, 2019

Published: 觜July 10, 2020

Volume 4 - Issue 3

How to cite this article: Kamil M, Ahmad F, Abdulla ET. Scientific Study on Trigonella Foenum-Graecum (Fenu Greek) with Special Reference to its Preclinical Study on Antidiabetic Effect. Interventions Obes Diabetes 4(3). IOD.000589. 2020. DOI: 10.31031/IOD.2020.04.000589

Copyright@ Kamil M. This article is distributed under the terms of the Creative Commons Attribution 4.0 International License, which permits unrestricted use and redistribution provided that the original author and source are credited.

\author{
Kamil M*, Ahmad F and Abdulla ET \\ TCAM Research, ZCHRTM, Abu Dhabi, United Arab Emirates
}

\section{Abstract}

Although earlier work on the hypoglycemic effect of Fenugreek (Trigonella foenum-graecum L. seed) extract have been carried out in many studies [1-9]. The present paper is a collective scientific study on Trigonella Foenum Graecum starting from its description, habitat, traditional and medicinal uses, pharmacognostic, physico-chemical and phytochemical protocols along with preclinical study of antidiabetic effect of Trigonella Foenum Graecum aqueous extract using experimental animals.

Keywords: Hypoglycemic effect; Gastrointestinal problems; Epidermal cells; Carbohydrates

\section{Description}

Annual herb $50-70 \mathrm{~cm}$ high. Glabrous or pubescent, stem erect. Leaves trifoliate, stipules triangular, leaflets obovate to oblong, 10-30 mm long, 5-15mm wide, obtuse to truncate at apex, narrowed towards the base; margins shallowly serrate to dentate; glabrous. Inflorescences short, axillary racemes; flowers small, white or cream, sessile or subsessile, solitary or paired, 13-18mm long. Fruits sickle-shaped, glabrous pods, 6-10(15) cm long, 3-5mm wide, sub cylindrical, tapering to a straight beak $2-3 \mathrm{~cm}$ long. Seeds $3-6$, oblong compressed, smooth, dark yellow to light brown when dry (Figure 1).

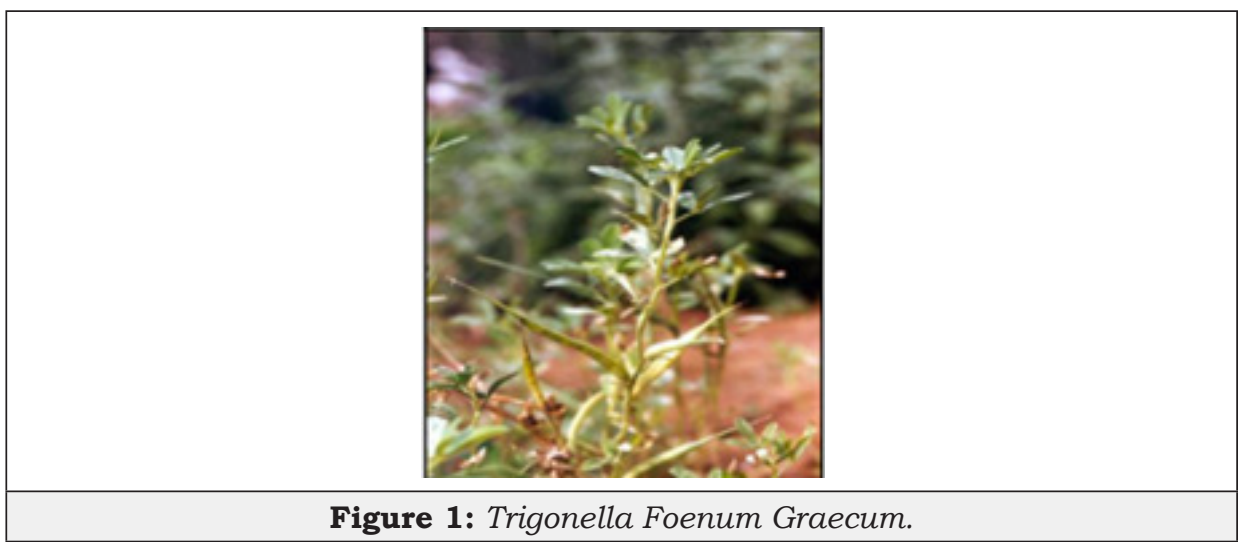

\section{Habitat \& distribution}

The plant is generally distributed in North Africa, Eastern Mediterranean and is cultivated all over the world and naturally grows in sandy, silty and clay soils. In UAE it is cultivated in private farms.

Part(s) used: Seeds and aerial parts

Traditional \& medicinal uses: The plant is tonic, emollient, lactagogue, nutritive, stomachic, diuretic, carminative, emmenagogue, condiment, aphrodisiac, expectorant, antidiabetic, anabolic, appetizer, insect repellent. Used orally to treat cough, asthma, dysuria, 
constipation, hemorrhoids, diarrhea, gastrointestinal problems, impotency, backache, bladder \& liver problems; and topically to treat tonsillitis, throat infections, swellings, abscesses, tumors and burns, scalp infection and dandruff and for hair and skin care $\&$ beauty. Seeds used as spice in curry powder or seed extract used in synthetic maple syrup, and maple, vanilla, caramel, and butterscotch flavors for the food industry.

\section{Pharmacognosy and phytochemistry}

Parts used: Seeds

Microscopic description: The seed is yellowish brown to light brown and more or less rhomboidal with rounded edges. It is $3 \mathrm{~mm}$ to $5 \mathrm{~mm}$ long, $2 \mathrm{~mm}$ to $3 \mathrm{~mm}$ wide and $1.5 \mathrm{~mm}$ to $2 \mathrm{~mm}$ thick.
The widest surfaces are marked by a groove that divides the seed into two unequal parts. The smaller part contains the radicle, the larger part contains the cotyledons. The seed testa is covered with a thick cuticle. The epidermis of the testa is composed of compact polygonal cells that have palisade-like shapes and straight cell walls and they contain a yellowish brown pigment. The epidermis is underlain by a single layer, the hypodermis, which is composed of characteristic colorless cells that have rod-like thickenings. The hypodermis is underlain by few layers of thin walled compact parenchyma cells. These are followed by the outer-most layer of the seed endosperm which has thick-walled cells. These cells are surrounding the endosperm mucilage cells. The cotyledons have compact parenchyma cells with thin cells walls (Figure 2).
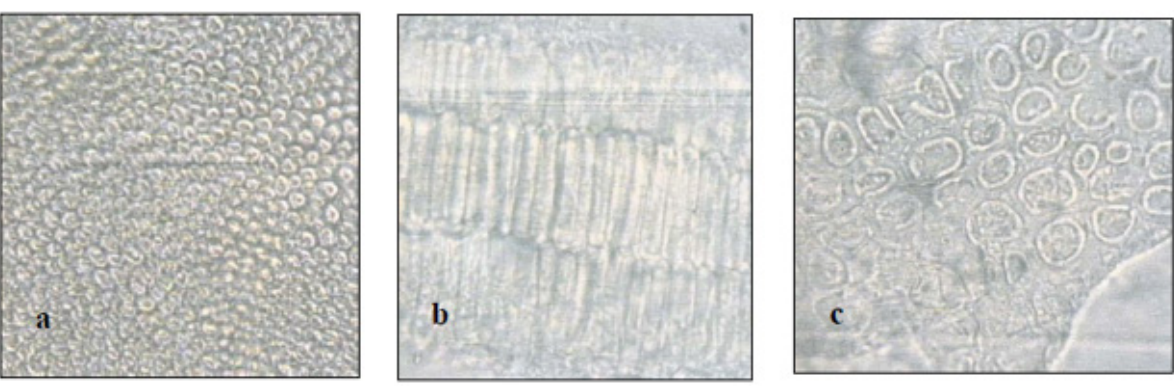

Figure 2: (a) Surface view for the epidermal cells of the testa from below showing the compactly packed cells. (b) The hypodermis of the testa in surface view from above.

(c) Layers of rod-like parenchyma cells of the palisade tissues of the cotyledons in sectional view. (Magnifications: All $\mathrm{x}$ 400).

The powder is yellowish-brown. Under the microscope the powder shows fragments of the testa in sectional view with thick cuticle covering palisade- like epidermal cells with an underlying hypodermis of large cells, narrow at the upper end and constricted in the middle, with bar-like thickening of the radial walls.

\section{Organoleptic characteristics}

a. Appearance: Solid- rhomboidal seeds

b. Colour: Yellowish brown-light brown

c. Odour: Specific of its own

d. Taste: Bitter

Table 1: Physicochemical constants.

\section{Chemical constituents}

Chromatographic studies: Different mobile phases were used to develop the thin layer chromatograms using petrol/ acetone, methanol extracts (Table 1). The following compounds were identified in the 'Fenugreek seeds 'taken in above solvents and on comparison with reference standards on TLC studies and GCMS analysis: Fenugreek seed contains carbohydrates, mainly mucilaginous fibre (galacto mannans); proteins, fixed oils (lipids), alkaloids, mainly trigonelline, gentianine, flavonoids, apigenin, luteolin, orientin quercetin, vitexin \& isovitexin. Free amino acids as 4-OH-isoleucine. Vitamins A, B \& C, saponins and steroids.

\begin{tabular}{|c|c|}
\hline \multicolumn{2}{|c|}{ Physicochemical Constants } \\
\hline Loss in weight on drying at $105^{\circ} \mathrm{C}(\%)$ & $5.80-7.00$ \\
\hline \multicolumn{2}{|c|}{ Solubilities(\%) } \\
\hline Alcohol solubility: & 6.4 \\
\hline Water solubility: & Not possible \\
\hline $10 \%$ ethanolic extractive: & Not done \\
\hline \multicolumn{2}{|c|}{ Ash Values (\%) } \\
\hline Total ash: & $3.50-6.00$ \\
\hline Water soluble ash: & $1.88-2.78$ \\
\hline Acid-insoluble ash : & $0.42-1.50$ \\
\hline \multicolumn{2}{|c|}{ Successive Extractive (\%) } \\
\hline Petroleum ether (60-800C): & 6.83 \\
\hline
\end{tabular}




\begin{tabular}{|c|c|}
\hline Chloroform: & 0.54 \\
\hline Absolute alcohol: & 8.2 \\
\hline Distilled water: & \\
\hline & pH Values \\
\hline pH of 1\% solution : & Not possible (Due to mucilaginous nature) \\
\hline pH of 10\% solution : & Not possible (Due to mucilaginous nature) \\
\hline
\end{tabular}

a. Trigonelline Pantothenic acid

b. Vitamin B1 Valeraldehyde

c. Sorbic acid Cyclopentanose-2-methyl

d. Niacin Tetrahydro-4H-pyran-4-ol

e. Glycerin 5-Hydroxymethylfurfuraldehyde

f. Glycerose 2-acetyl-2-hydroxy.gamma.butyrolactone

g. Guanosine 4H-Pyran-4-one-2, 3-hydro-3, 5-hydroxy-6methyl

h. Di acetine Propionic acid-2methyl, 2-ethyl-3-hydroxy3-hydroxy-

i. Lactone G -ethyl ester Triacetine

j. Riboflavin

\section{Pharmacological study}

Animals: Experimental animals of either sex were obtained from the LSSU, ZCHRTM. They were maintained under controlled conditions of temperature, humidity, light, ventilation and fed on standard rat chow and had free access to water. $40 \mathrm{~T} / 0$ mice 20 male and 20 females marked, distributed and kept into Makrolon cages with stain less steel grids with place for food and water bottle with nozzle, 10 mice per cage.

Species: Albino mice/ TO

Age/Sex: 6-8 weeks

Body weight range: $25-30 \mathrm{~g}$ for mice

Identification Method: Fur coloring.

\section{Reagent preparation}
a. Na-Citrate Buffer
b. Streptozotocin (STZ)
c. STZ-Na-Citrate Solution
d. Na-Citrate Buffer

\section{Procedure}

a. $1.47 \mathrm{~g}$. of Na Citrate dissolved in $50 \mathrm{ml} \mathrm{ddH} 2 \mathrm{O}$.

b. $\mathrm{pH}$ tested with $\mathrm{pH}$ meter, adjust buffer to $4.5 \mathrm{pH}$ with monohydrate Na Citrate solution. c. Buffer was prepared fresh with every group of injections

d. Appropriate amount of buffer placed into a sterile conical tube.

\section{Streptozotocin (STZ)}

Reagents and Materials

a. (STZ) \#S-0130 Sigma supplied.

b. Eppendorf tube

c. Aluminum foil

\section{Procedure}

Concentration: $7.5 \mathrm{mg} / \mathrm{ml}$

a. STZ stored at $-20^{\circ} \mathrm{C}$ to avoid desiccation.

b. Appropriate amount of STZ weighed so the final concentration in the Na-Citrate buffer will be $7.5 \mathrm{mg} / \mathrm{ml}$ and this placed into an Eppendorf tube covered with aluminum foil (light sensitive).

\section{STZ Na-Citrate solution}

Reagent/Material
a. Na-Citrate Buffer from above
b. STZ weighed from above
c. $\quad 3 \mathrm{ml} 23$ gauge syringe/needle
d. Empty sterile vial

\section{Protocol}

Mice have been fasted for four (4) hours prior to STZ induction. The consortium has agreed that a proper fasting for the mice 4-6 hours. (Some of the other institutions may fast for 6 hours); we have chosen 4 hours as a proper fasting time. The STZ-Na Citrate buffer solution was prepared immediately before injection as the drug degrades after 15-20 minutes in the Na-Citrate buffer.

a. Prepare the buffers and solutions as described below. Please note that the STZ-Na-Citrate solution should be prepared immediately prior to injection to avoid degradation of the STZ.

b. Mice should be fasted prior to injection; four hours is usually sufficient.

c. Mouse placed in the Isoflurane drop jar, according to the local IACUC anesthesia standards. 
d. The mouse removed when breathing has slowed, and animal is anesthetized

e. Appropriate amount of the STZ solution Injected IP so the final dosage is $50 \mathrm{mg} / \mathrm{kg}$ mouse.

f. The mouse allowed to awake and placed back in cage.

g. The procedure repeated for each animal; Isoflurane reloaded after every third or fourth animal for proper anesthesia.

h. Supply mice with $10 \%$ sucrose water, if necessary, to avoid sudden hypoglycemia post-injection.

i. Mice have been tested for sufficient levels of hyperglycemia at 4 weeks post-injection. Low dose of STZ was re-administered to the experimental animals which are not sufficiently diabetic to obtain proper levels of hyperglycemia.

\section{Procedure}

Concentration: $7.5 \mathrm{mg} / \mathrm{ml}$ Dosage: $50 \mathrm{mg} / \mathrm{kg}$ mouse

a. STZ mixed into buffer just before injection; the drug degenerates within 15-20 minutes in solution.

b. The contents of Eppendorf tube (STZ) poured into the conical (buffer) and well mixed.

c. The solution aspirate using a $3 \mathrm{ml} 23$ gauge syringe/ needle (This repeated several times depending on amount of solution).

d. The contents saved into the empty sterile vial.

e. Vial contains solution ready for injecting the mice.

Trigonella water extract: The plant identified, and extract was prepared at the TCAM Research Lab., ZCHRTM.

GM9 Glucose analyzer (ANOLOX): The GM9 Glucose Analyzer (ANOLOX) used for glucose quantification $\mathrm{g} / \mathrm{dl}$. The GM9 is a compact system that offers accurate blood glucose readings.

Test procedure: From the $40 \mathrm{STZ}$ injected mice, 23 mice with homogenous blood glucose level selected, 10 mice used as control group and 13 ones as treated group. The Trigonella extract dissolved in distilled water and administered orally $2 \mathrm{~g} / \mathrm{kg}$, body weight to the mice treated group and water to the control group. The blood glucose was checked at (30min, $1 \mathrm{hr}$ and $2 \mathrm{hrs}$ ) after the administration of the extract.

\section{Result}

The hypoglycemic effect of Trigonella extract compared with that of the control. The extract showed significant activity against the diabetic state induced by STZ. A statistically significant is calculated using student's t-test; by comparing the data results of the treated mice by test substance (Blood glucose level g/dl) with that of vehicle control [Figures 3 \& 4]. It is considered significant positive activity when the treated values is less than that of the control and the student's t-test is $\mathrm{p}<0.05$. (The statistical limits $\mathrm{p}<$ $0.05, \mathrm{p}<0.01 ; \mathrm{p}<0.001$ ).
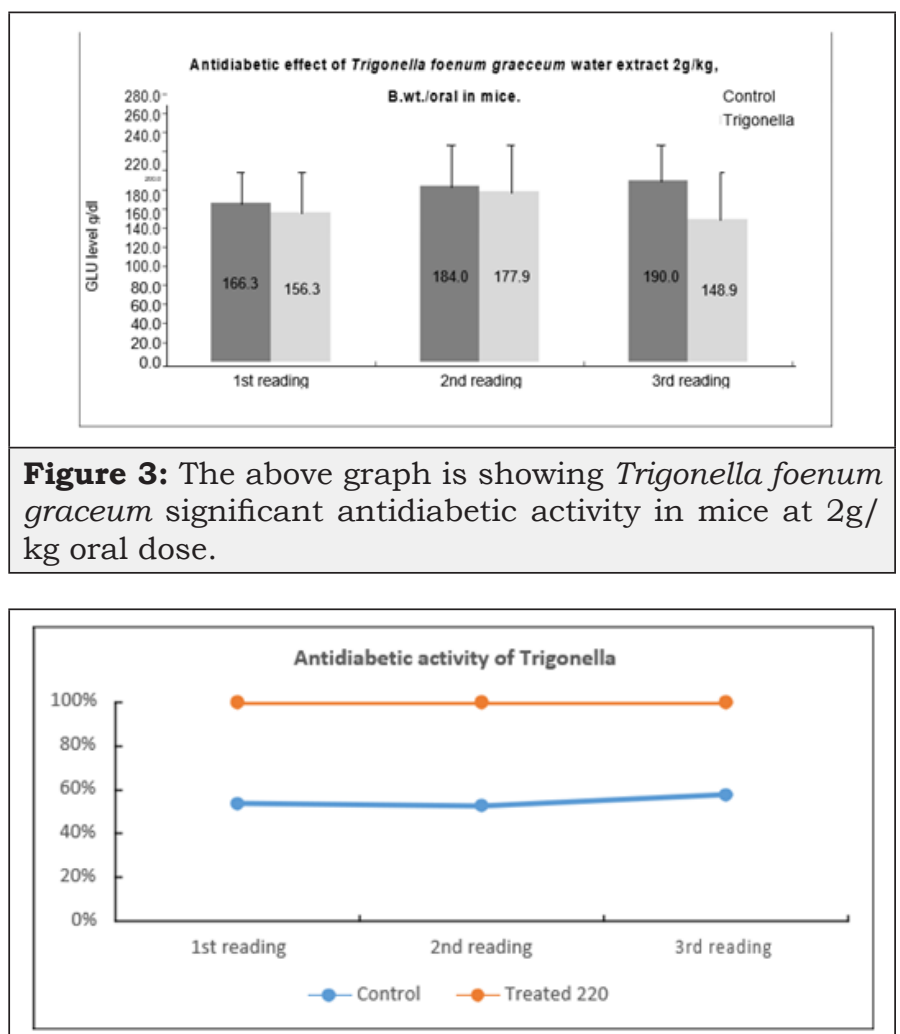

Figure 4: Antidiabetic activity of Trigonella foenum graceum.

\section{References}

1. Mowla A, Alauddin M, Rahman A, Ahmed K (2009) Antihyperglycemic Effect of Trigonella foenum-graecum (Fenugreek) seed extract in alloxan-induced diabetic rats and its use in diabetes mellitus: A brief qualitative phytochemical and acute toxicity test on the extract. Afr J Tradit Complement Altern Med 6(3): 255-261.

1. Puri D, Prabhu KM, Murthy PS (2002) Mechanism of action of a hypoglycemic principle isolated from fenugreek seeds. J Physiol Pharmacol 46(4): 457-462.

2. Gupta A, Gupta R, Lal B (2001) Effect of Trigonella foenum-graecum (fenugreek) seeds on glycaemic control and insulin resistance in type 2 diabetes mellitus: A double blind placebo controlled study. J Asso Phys India 49: 1057-1061.

3. Abdel Barry JA, Abdel Hassan IA, Jawad AM, Al Hakiem MH (2000) Hypoglycaemic effect of aqueous extract of the leaves of Trigonella foenum-graecum in healthy volunteers. East Mediterr Health J 6(1): 83-88.

4. Genet S, Kale RK, Baquer NZ (1999) Effects of vanadate, insulin and fenugreek (Trigonella foenum graecum) on creatine kinase levels in tissues of diabetic rat. Indian J Exp Biol 37(2): 200-202.

5. Petit P, Sauvaire Y, Ponsin G, Manteghetti M, Fave A, et al. (1993) Effects of a fenugreek seed extract on feeding behaviour in the rat: Metabolic-endocrine correlates. Pharmacol Biochem Behav 45(2): 369-374.

6. Hafeez BB, Haque R, Parvez S, Pandey S, Sayeed I, et al. (2003) Immunomodulatory effects of fenugreek (Trigonella foenum graecum $\mathrm{L}$.) extract in mice. Int Immunopharmacol 3(2): 257-265. 
7. Khlifi S, Jemaa HB, Hmad HB, Abaza H, Karmous I, et al. (2016) Antioxidant, antidiabetic and antihyperlipidemic effects of Trigonella foenum-graecum seeds. International Journal of Pharmacology 12(4): 394400.
8. Prem kumar N, Arunachalam A, Ram Sharnagat T (2009) Antinociceptive property of Trigonella foenum graecum (fenugreek seeds) in high fat diet-fed/low dose streptozotocin induced diabetic neuropathy in rats. Pharmacologyonline 2: 24-36.

For possible submissions Click below: 